\title{
Immunohistochemical Study Of Fibronectin, Tenascin and Type I Collagen In Tongue And Lip carcinomas
}

\author{
João Luiz de Miranda, $\mathrm{PhD}^{1}$, Felipe Rodrigues \\ de Matos, PhD ${ }^{2}$, Frederico Santos Lages, $\mathrm{MSc}^{3}$, \\ Dhelfeson Willya Douglas-de-Oliveira, $\mathrm{MSc}^{3}$, Roseana \\ de Almeida Freitas, PhD 4
}

\begin{abstract}
1 Dentistry Department Federal University of Vales do Jequitinhonha e Mucuri, Diamantina - MG, Brazil.

${ }^{2}$ Dentistry School, Federal University of Sergipe, Aracaju - SE, Brazil.

${ }^{3}$ Periodontology Department, Federal University of Minas Gerais, Belo Horizonte - MG, Brazil.

${ }^{4}$ Oral Pathology Post Graduate Program, Federal University of Rio Grande do Norte, Natal - RN, Brazil.
\end{abstract}

Corresponding author: Prof. João Luiz de Miranda Rua da Glória, 187, Centro, Diamantina, Minas Gerais, Brazil. Zip code: 39100-000

Phone:+55 3835326082

joao.miranda.ufvjm@gmail.com

Received: April 17, 2017

Accepted: September 14, 2017
Aim: The aim was to compare the immunoexpression of extracellular matrix proteins in squamous cell carcinomas of tongue (SCCTo) and lower lip (SCCLi). Methods: Eleven SCCTO and 11 SCCLi were selected and examined according to Bryne's method (1998). For immunohistochemical study utilized antibodies to fibronectin, tenascin and type I collagen. Histopathologic and immunohistochemical analysis were performed on the tumor invasive front. Results: All SCCTo were classified in high score malignant grade and all SCCLi in lower score. Fibronectin showed strong immunorreactivity in the peritumoral basement membrane (BM) in 91\% of SCCTo and all cases of SCCLi, while in the tumor stroma (TS) all cases of SCCTo and SCCLi had strong intensity. Tenascin had strong expression in BM of $91 \%$ cases of SCCTo and $63.4 \%$ of SCCLi and in TS had strong expression in 91\% cases of SCCTo and $54.6 \%$ of SCCLi. Type I collagen demonstrated weak immunoreactivity in the TS of $72.7 \%$ cases of SCCTO and $63.4 \%$ of SCCLi. Conclusion: These results may suggest that the strong expression of fibronectin and tenascin proteins and the weak expression of type I collagen could play a role in the invasive process of oral SCC.

Keywords: immunohistochemistry; oral cancer; tenascin; fibronectin; collagen. 


\section{Introduction}

oral squamous cell carcinoma (SCC) is the most common type of oral cancer, and it continues to have a poor 5 years survival rate ${ }^{1,2}$. Identification of specific molecules associated with malignant transformation has led to identify an increasing number of molecular markers related to tumor stage and grading, and it may have a prognostic value for the disease. In addition, there is significant knowledge about key molecules that regulate the cell cycle, apoptosis, immunologic tumor defense, and extracellular matrix interactions and breakdown in oral cancer ${ }^{3,4}$.

It has been postulated that tumorigenesis of oral SCC is not dependent only on the type, duration and level of exposure to a specific carcinogen, but rather on the genetic sensitivity of the individual ${ }^{5}$.

Studies of clinical, morphological and immunohistochemical features have been conducted to demonstrate that the SCC with poor prognosis show more proliferative activities $^{6,7}$, less differentiation ${ }^{6}$, more vascularization ${ }^{8}$ and more invasive ${ }^{7}$ and spreading potential ${ }^{9,10}$ in the adjacent and distant tissues.

The SCC dissemination is possible elsewhere, and they lose the intercellular adhesion and initiate the migration mechanism into the basal lamina ${ }^{11,12}$. This migratory mechanism depends on the disrupting of the basal membrane ${ }^{11-13}$. In similar manner, the carcinoma cells migrated into tumor stroma degrading the interstitial collagen ${ }^{14}$. At this stage, these carcinoma cells expressed superficial receptors to extracellular matrix (ECM) components aiming to penetrate more freely the adjacent connective tissue ${ }^{11,12,14}$.

Fibronectin is a ubiquitous protein present in tissues and body fluids, including plasma that engages in these cellular functions and provides architectural scaffolding for cells and tissues, and it may be associated with invasion and metastasis. Therefore, fibronectin variants could be used as possible prognostic factor ${ }^{15}$. Tenascin is another protein of ECM that is a glycoprotein expressed in epithelial-mesenchymal interactions during embryogenesis and tumorigenesis of several tissues ${ }^{16}$. Tenascin plays an important role as a molecular mediator in proliferation and progression in neoplastic processes ${ }^{17}$. Additionally, increased synthesis and deposition of type I collagen by stromal cells has been described in mammary, skin, colon, and prostate carcinomas ${ }^{18-21}$.

SCCs of the tongue (SCCTo) and lower lip (SCCLi) reveal differences in their biological behavior. SCCTo has a great predisposition to produce metastasis in lymph nodes (incidence $15-75 \%$ ) depending on the extension of the primary lesion ${ }^{22,23}$. The aim of this study was to verify the extracellular matrix protein expression (fibronectin, tenascin and type I collagen) in squamous cell carcinoma of tongue and lower lip, in an attempt to establish some comparison between these protein expressions and the biological behavior of the oral SCC.

\section{Materials and Methods}

\subsection{Sample Size}

Sample size was calculated based on the prevalence $(1,4 \%)$ of squamous cell carcinomas ${ }^{24}$ with the margin of error set at $5 \%$. The minimum sample size required was 21 SCCs considering a 95\% confidence level. 


\subsection{Patients}

The study was approved by the Ethics Committee of the Federal University of Vales do Jequitinhonha e Mucuri under protocol number 122/2010. It was conducted according to the Declaration of Helsinki 1975, revised in 2013. Eleven cases of tongue squamous cell carcinoma and eleven of lower lip squamous cell carcinoma were obtained from the files of Laboratory of Pathology of Federal University of Vales do Jequitinhonha e Mucuri. Patients were surgically treated without radiotherapy or chemotherapy prior. Samples were excluded from the study in case of incision biopsy, specimens with inadequate material or extensive areas of necrosis. Each patient assigned a written informed consent at the moment of biopsy.

Sections $(5 \mu \mathrm{m})$ were cut from paraffin-embedded tumor specimens and stained with hematoxylin and eosin for the grading of histological malignancy as proposed by Bryne's method ${ }^{25}$, utilizing the histological parameters as degree of keratinization (DK), nuclear polymorphism (NP), pattern of invasion (PI) and lymphoplasmatic infiltration (LI). A score of 0 to 4 was attributed to each parameter and cases with a total score of 8 or lower were classified as low-grade malignancy and those scoring higher than 8 were classified as high-grade malignancy ${ }^{26}$.

\subsection{Immunohistochemistry}

For the immunohistochemical study, the tissue sections were deparaffinized and immersed in $3 \%$ hydrogen peroxide to block endogenous peroxidase activity. The tissue sections were then washed in phosphate-buffered-saline (PBS). The antigen retrieval, antibody dilution and clone type for fibronectin, tenascin and type I collagen are shown in Table 1. After treatment with normal serum, the tissue sections were incubated in a moist chamber with primary antibodies. The tissue sections were then washed twice in PBS and treated with streptoavidin-biotin-peroxidase complex (Dako, Carpinteria, CA, USA) at room temperature in order to bind the primary antibodies. Peroxidase activity was visualized by immersing tissue sections in diaminobenzidine (D5637; Sigma Chemical, St. Louis, MO), resulting in a brown reaction product. Finally, tissue sections were counterstained with Mayer's hematoxylin and coverslipped. Positive controls for fibronectin and tenascin were sections of normal oral mucosa and for type I collagen were sections of human placenta. As negative controls, samples

Table 1. Specificity, dilution, antigen retrieval, and incubation of the antibody (Ab) clones.

\begin{tabular}{lcccc}
\hline Ab clone & Specificity & Dilution & Antigen retrieval & Incubation \\
\hline A-245 $\ddagger$ & Fibronectin & $1: 500$ & $\begin{array}{c}\text { Pepsin } 1 \%, \mathrm{pH} 1.8, \text { oven } 37^{\circ} \mathrm{C}, \\
60 \mathrm{~min}\end{array}$ & $120 \mathrm{~min}$ \\
\hline TN2 $\ddagger$ & Tenascin & $1: 100$ & $\begin{array}{c}\text { Pepsin } 0.4 \%, \mathrm{pH} 1.8, \text { oven } \\
37^{\circ} \mathrm{C}, 30 \mathrm{~min}\end{array}$ & Overnight (18 h) \\
\hline NCL-COLL-Ip * & Type I collagen & $1: 40$ & Citrate pH 6.0, Steamer, 5min & Overnight (18 h) \\
\hline
\end{tabular}

* Novocastra Laboratories.

$\ddagger$ Dako 
were treated as above, except that the primary antibody was replaced by a solution of bovine serum albumin (BSA) in PBS.

\subsection{Immunohistochemical analysis}

The immunohistochemical analysis for fibronectin, tenascin and collagen I was performed using light microscope at $\times 400$ magnification for its location (basement membrane and stroma peritumoral) and intensity. The thickness of basement membrane was measured as $5 \mu \mathrm{m}$ at the tumor front. The intensity of immunoreactivity was semiquantitatively assessed by two independent observers (Kappa = 0.89 ) to remove any possible bias using a modification of criteria indicated as: weak (absence or weak staining) and strong (moderate or intense staining).

The results obtained were submitted to statistical analysis. Computations were made using the Statistical Package for the Social Sciences (version 22.0; SPSS Inc., Chicago, $\mathrm{IL}$ ). The association of the fibronectin, tenascin and collagen expression between SCCTo and SCCLi was performed by Fisher's exact test. For all tests, significance level was set $p<0.05$.

\section{RESULTS}

The histological gradation system utilized demonstrated that all SCCLi $(n=11)$ had low malignant grade and all cases of SCCTo $(n=11)$ have high malignant grade (Table 2). There was significant association between the location and the grade of the SCC $(P<0.001)$.

Table 2. Malignancy grading of the squamous cell carcinomas of the lower lip and tongue.

\begin{tabular}{lccccc}
\hline & \multicolumn{2}{c}{ High malignant grade } & \multicolumn{2}{c}{ Lower malignant grade } & \\
\cline { 2 - 5 } & $\mathbf{n}$ & $\%$ & $\mathbf{n}$ & $\mathbf{p}^{*}$ \\
\hline Lower lip & 0 & 0.0 & 11 & 100 & $<0.001$ \\
\hline Tongue & 11 & 100 & 0 & 0.0 & \\
\hline
\end{tabular}

All cases of SCCTo (Fig. 1) and SCCLi (Fig. 2) exhibited fibronectin immunoexpression throughout peritumoral basement membrane (BM) and tumor stroma (TS), which was mainly linear and thin in the BM and diffuse and fibrillar in the TS. In the BM, all cases of SCCLi and 10 (91\%) cases of SCCTo showed strong intensity without significant difference between groups (Table 3). In the TS, this protein demonstrated strong intensity in all SCCTo and SCCLi (Table 3).

Tenascin immunoexpression was observed in BM of 10 cases of SCCTo (Fig. 3a and 3b) and 8 cases of SCCLi (Fig. 4), characterized by linear and thin pattern. Ten (91\%) cases of SCCTo and 7 (63.4\%) of SCCLi had strong expression with no significant difference $(P>$.05) (Table 3). At the TS, all cases of SCCTo and SCCLi was immunopositive and showed diffuse and fibrillar expression of this protein. Ten 


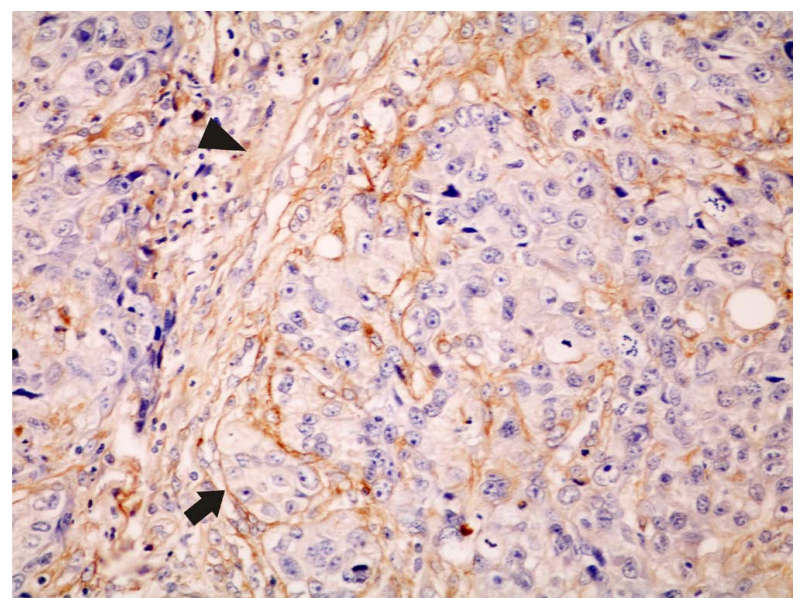

Figure 1. Immunoexpression of fibronectin in SCCTo throughout peritumoral basement membrane (arrow) and tumor stroma (arrowhead) (Labelled Streptavidin Biotin (LSAB) method, original magnification $\times 400$ ).

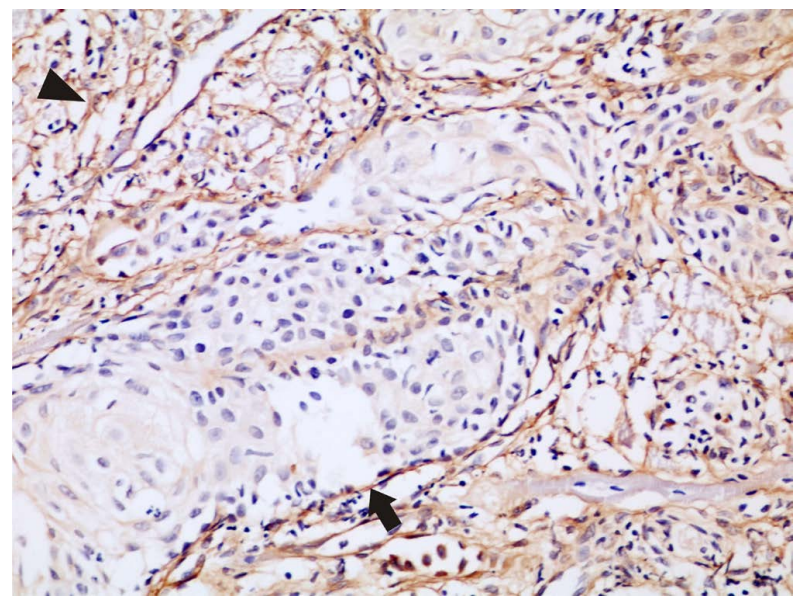

Figure 2. Immunoexpression of fibronectin in SCCLi throughout peritumoral basement membrane (arrow) and tumor stroma (arrowhead) (LSAB method, original magnification $\times 400)$.

Table 3. Distribution of percentages of the intensity of fibronectin, tenascin and type I collagen in SCCTo and SCCLi, according localization.

\begin{tabular}{|c|c|c|c|c|c|c|c|c|c|c|}
\hline \multirow{2}{*}{ Localization } & \multirow{2}{*}{ Intensity } & \multicolumn{2}{|c|}{ Fibronectin } & \multirow{2}{*}{$p$} & \multicolumn{2}{|c|}{ Tenascin } & \multirow{2}{*}{$p$} & \multicolumn{2}{|c|}{ Type I collagen } & \multirow{2}{*}{$p$} \\
\hline & & SCCTo & SCCLi & & SCCTo & SCCLi & & SCCTo & SCCLi & \\
\hline \multirow{2}{*}{$\begin{array}{l}\text { Basement } \\
\text { membrane }\end{array}$} & $\begin{array}{l}\text { Weak n } \\
(\%)\end{array}$ & $\begin{array}{c}1 \\
(9 \%)\end{array}$ & $\begin{array}{c}0 \\
(0.0 \%)\end{array}$ & \multirow{2}{*}{0.999} & $\begin{array}{c}1 \\
(9 \%)\end{array}$ & $\begin{array}{c}4 \\
(36.3 \%)\end{array}$ & \multirow{2}{*}{0.311} & $\begin{array}{c}11 \\
(100 \%)\end{array}$ & $\begin{array}{c}11 \\
(100 \%)\end{array}$ & \multirow{2}{*}{ NA } \\
\hline & $\begin{array}{c}\text { Strong n } \\
(\%)\end{array}$ & $\begin{array}{c}10 \\
(91 \%) \\
\end{array}$ & $\begin{array}{c}11 \\
(100 \%)\end{array}$ & & $\begin{array}{c}10 \\
(91 \%) \\
\end{array}$ & $\begin{array}{c}7 \\
(63.4 \%) \\
\end{array}$ & & $\begin{array}{c}0 \\
(0.0 \%)\end{array}$ & $\begin{array}{c}0 \\
(0.0 \%)\end{array}$ & \\
\hline \multirow{2}{*}{$\begin{array}{l}\text { Tumor } \\
\text { stroma }\end{array}$} & $\begin{array}{l}\text { Weak n } \\
(\%)\end{array}$ & $\begin{array}{c}0 \\
(0.0 \%)\end{array}$ & $\begin{array}{c}0 \\
(0.0 \%)\end{array}$ & \multirow{2}{*}{ NA } & $\begin{array}{c}1 \\
(9 \%)\end{array}$ & $\begin{array}{c}5 \\
(45.4 \%)\end{array}$ & \multirow{2}{*}{0.149} & $\begin{array}{c}8 \\
(72.7 \%)\end{array}$ & $\begin{array}{c}7 \\
(63.4 \%)\end{array}$ & \multirow{2}{*}{0.999} \\
\hline & $\begin{array}{c}\text { Strong } n \\
(\%)\end{array}$ & $\begin{array}{c}11 \\
(100 \%)\end{array}$ & $\begin{array}{c}11 \\
(100 \%)\end{array}$ & & $\begin{array}{c}10 \\
(91 \%)\end{array}$ & $\begin{array}{c}6 \\
(54.6 \%)\end{array}$ & & $\begin{array}{c}3 \\
(27.3 \%)\end{array}$ & $\begin{array}{c}4 \\
(36.3 \%)\end{array}$ & \\
\hline
\end{tabular}

NA = not applied 

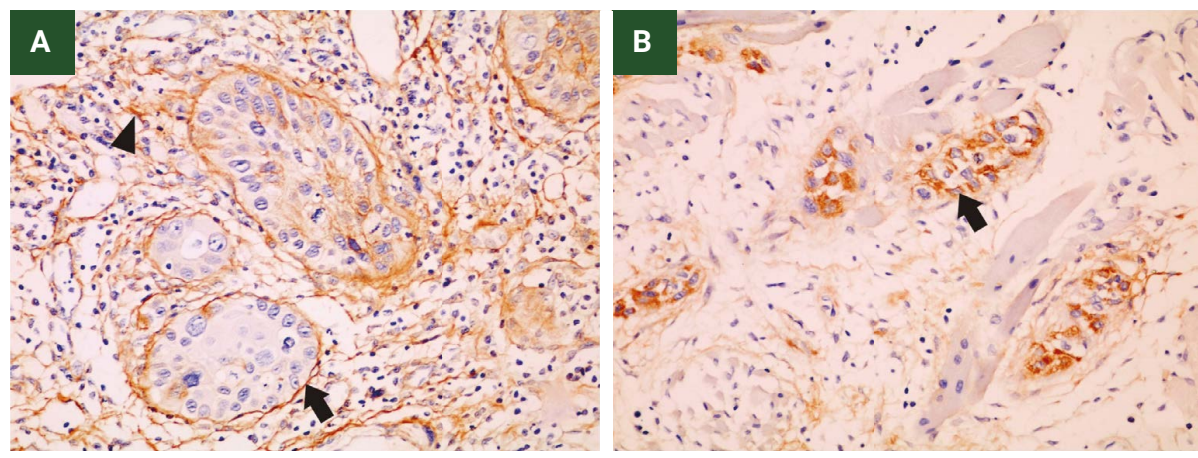

Figure 3. a) Immunoexpression of tenascin in SCCTo throughout peritumoral basement membrane (arrow) in linear and thin pattern and tumor stroma (arrowhead) (LSAB method, original magnification $\times 400$ ). b) Intense cytoplasmic immunoexpression of tenascin in deepest nests (arrow) (LSAB method, original magnification $\times 400)$.

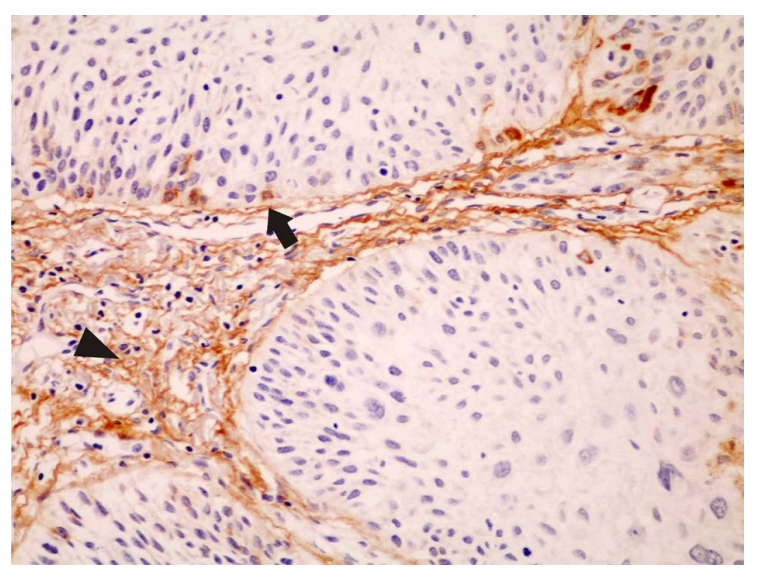

Figure 4. Immunoexpression of tenascin in SCCLi throughout peritumoral basement membrane (arrow) in linear and thin pattern and tumor stroma (arrowhead) (LSAB method, original magnification $\times 400$ ).

(91\%) cases of SCCTo and 6 (54.6\%) of SCCLi had strong expression with no significant difference $(P>.05)$ (Table 3).

All cases of SCCTo and SCCLi were non-reactives in BM for type I collagen (Table 3). At the TS, all cases of SCCTo (Fig. 5) and SCCLi (Fig. 6) had immunoexpression of this protein characterized by predominant fibrillar pattern. Eight (72.7\%) cases of SCCTo and 7 (63.4\%) of SCCLi (Fig. 5) had weak expression with no significant difference $(P>$.05) (Table 3).

\section{DISCUSSION}

Many studies about the biological behavior of the oral squamous cell carcinoma have been developed, seeking histomorphological parameters for the malignant grading systems for this carcinoma and aiming to find new prognostic indicators ${ }^{25-27}$. 


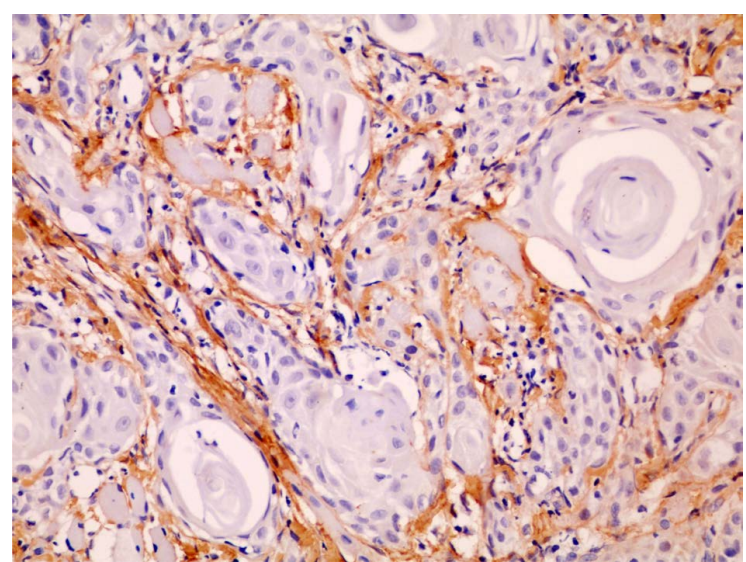

Figure 5. Immunoexpression of type I collagen in tumor stroma of SCCTo in fibrillar pattern (LSAB method, original magnification $\times 400$ ).

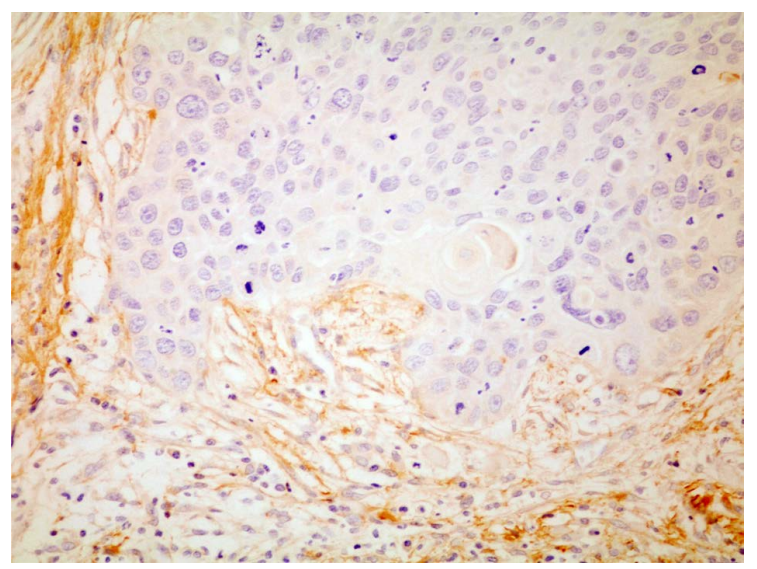

Figure 6. Immunoexpression of type I collagen in tumor stroma of SCCLi in fibrillar pattern (LSAB method, original magnification $\times 400)$.

The histomorphologic results of our study suggest that the SCCTo have more aggressive biological behavior than the SCCLi, since we observed that all SCCTo were high malignant grade compared to the SCCLi. These observations also have been demonstrated by several other studies ${ }^{27-29}$. The tongue is located in the floor of the oral cavity, which has a rich supply of lymphatic drainage and neurovascular bundles, thus increasing the probability that neck nodal metastasis could occur in tongue cancer patients ${ }^{30}$.

But not only supplies of lymphatic drainage and neurovascular bundles are responsible for aggressiveness and invasion of the tumor cells. It has been clearly established in the literature that tumor stroma is directly related with biological behavior of neoplasm, despite the fact that for a long time, neoplasm cells were the main focus of cancer studies. The capability malignant cells have to destroy basal membrane and the other 
components of extracellular matrix (ECM) have been related to invasive potential of the $\mathrm{SCC}^{12}$. ECM constituents contribute directly or indirectly to the tumor process, owing to the fact that the structure has potentially anti-adhesive components, modulators of adhesion, proliferation and cell migration. ECM may regulate cell behavior using different mechanisms: first through composition of proteins in a specific tissue and second in synergic interactions between growth factors and adhesion molecules or cell receptors that mediate adhesion of components ${ }^{31}$. Recent studies have shown that the ECM does not only act passively as a support for cells, but also provides information to these cells modifying their behavior, an event that might be responsible for tumorigenesis ${ }^{32,33}$. Some studies using markers for different constituents of EMC, like fibronectin ${ }^{34,35}$, tena$\operatorname{scin}^{36,37}$ and collagen ${ }^{38}$, were conducted to clarify the role of this structure in the process of tumorigenesis and progression of head and neck tumors.

Fibronectin is a high-molecular-mass glycoprotein with additional domain in the IIICS region ${ }^{39}$ and is not restricted to the basement membrane but is ubiquitously distributed throughout the cell matrix, and a soluble plasma fibronectin is found in body fluids ${ }^{40}$. Fibronectin plays an important signaling function in cell adhesion and migration and interacts with a number of integrins, including $\alpha_{v} \beta_{6}$. Its expression has been related to poor prognosis of head and neck tumors ${ }^{12,40}$, since cell migration on a fibronectin matrix is significantly faster in those cell lines expressing higher levels of $\alpha_{v} \beta_{6}$ integrin ${ }^{40}$. Hypoxia promotes cancer cell invasion by inducing the expression of mesenchymal cell markers such as fibronectin ${ }^{41}$. Through the immunohistochemical evaluation we observed strong expression of fibronectin in the basement membrane of the neoplastic epithelial nests of all SCCLi.

In the tumor stroma of the invasion front, the fibronectin exhibited strong immunorreactivity in all SCCTo and SCCLi. The expression of fibronectin was significantly increased in the stromal tissue of $50 \%$ of the SCC but only in $10 \%$ of cases of verrucous carcinoma (VC) that is an uncommon rare low-grade variant of SCC ${ }^{42}$. The results of our study suggest that the intense expression of the fibronectin may be involved in the migratory and invasive mechanisms of the neoplastic cells of the SCC studied, since cancer cells degrade the ECM and invade the surrounding stroma by producing proteases and the degraded ECM may be replaced by fibronectin ${ }^{41}$. This may be indicative that tumor cells and not only stromal cells may synthesize fibronectin, building up on the basal membrane and peritumor matrix to probably facilitate adherence and posterior migration through tumor stroma. This data helps to better comprehend the molecular mechanisms involved in the cellular invasion process.

Whereas fibronectin induces the cell to adhere to the substrate strengthening and spreading, tenascin has the opposite effect of promoting rounding and detachment. Tenascin has a modulatory effect on cell-interactions and in cell culture that antagonizes the adhesive effects of fibronectin. Although tenascin and fibronectin are usually found together, regulatory mechanisms for each of them are quite different ${ }^{43}$.

Tenascin is another glycoprotein synthesized at specific time points and sites during embryogenesis, it is absent or greatly reduced in most adult tissue, but it increased in some pathological conditions, inclucing inflammation, wound healing and in a variety of neoplasias ${ }^{44}$. As observed in the present study, tenascin expression was associated with invasiveness and malignancy. 
Tenascin is an extracellular matrix protein composed of six monomers linked at their $\mathrm{N}$-termini with disulfide bounds to form a 1080-1500-kDa hexamer and various solid tumors express high level of tenascin ${ }^{45}$. Tenascin is secreted from both tumor cells and fibroblasts. The most prominent effects of tenascin are anti-adhesion and inhabitation of cell attachment, both of which favor cancer cell motility and invasion ${ }^{46}$. Furthermore, tenascin promotes malignant transformation, uncontrolled proliferation, metastasis, angiogenesis, drug resistance and escape from tumor immunosurveillance $^{33}$. For this reason, there was difference in the amount of tenascin, which was more intense in the stroma of tongue (91\%) than is lip (55\%) cases.

The highest expression of tenascin is observed in unstable environments such as during cell migration, in active areas of epithelial-mesenchymal interactions, and in neoplastic stroma. This protein had many domains of binding, mediating cell-cell adhesion, cell migration, as well as cell adhesion close to matrix through fibronectin binding to proteoglicans. Tenascin may have a complex structure with domains that are capable of interacting with a variety of cell-surface receptors, including integrins and extracellular matrix proteins ${ }^{40}$. When this protein is produced by malignant neoplastic cells, there seems to be an increase in proliferation and migration, probably owing to the fact that it has antiadhesive properties, because it blocks binding of fibronectin to cells $s^{12,47}$.

The higher expression of tenascin in SCCTo in basement membrane and tumor stroma when compared to SCCLi might suggest a strong interaction between parenchyma and stroma in order to create a microenvironment permissive to the high proliferative activity and invasive capacity of tumor cells. Probably, these findings were associated with the fact that the SCCTo demonstrated high malignant score and a diffuse cellular invasion pattern. During the initiation of oral cancer, tenascin could be directly produced by cancer cells and is responsible for the acquisition of an invasive phenotype ${ }^{48}$. Tenascin and laminin in oral SCC at the tumor margins by a laser scanning microscopy-based quantitative co-localization and verified the extent of tenascin and laminin arrangement into reorganized basement membrane structures correlated with malignancy grade ${ }^{47}$. Thus, these results suggest that the tenascin contributes to a major migration and spreading of the malignant neoplastic cells.

Collagen represents a family of characteristic proteins with over 20 known types, present in all multicellular animals, being the most abundant components in all $\mathrm{ECM}^{12}$. Over 20 genetically distinct collagens have been identified. Type I collagen is found throughout the connective tissue and is one of the most abundant components of the interstitial ECM, being highly resistant to proteases due to its unique supercoiled triple helix structure. Paradoxically, despite being the commonest molecule of the matrix, few tumor-associated changes are apparent and these seem to be of little prognostic significance ${ }^{40}$, although some studies have demonstrated discontinuity of different types of collagen during the process of tissue invasion by neoplastic cells ${ }^{38,49}$.

Type I collagen presented weak intensity predominantly in tumor stroma of SCCTo and SCCLi. Recent studies have also documented a significant higher frequency of less packed collagen fibers at the sites of invasion, whereas the well packed ones predominated at the noninvaded sites. It was assumed that the less packed collagen fibers, together with other molecular events, could facilitate invasion into adjacent tis- 
sues and development of metastasis ${ }^{50}$. The type I collagen was deposited in a minor quantity in the peritumoral stroma of the oral $\mathrm{SCC}^{38}$. These results are consistent with previous studies reporting that during the cellular invasion processes, the malignant neoplastic cells $\mathrm{s}^{6,79,910}$, and stromal fibroblasts ${ }^{51,52}$ degrade the collagen by the production of proteolytic enzymes, stimulated by transforming growth factor-beta (TGF- $\beta$ ) production ${ }^{53}$. However, other studies verified that the type I collagen is a good substrate in the adherence and migration of the malignant neoplastic cells, suggesting that this collagen plays an important promoter role in tumoral metastasis ${ }^{52,53}$

The present results may suggest that the strong expression of fibronectin and tenascin proteins and the weak expression of type I collagen could play a role in the invasive process. Over the years, oral cancer diagnosis and therapy have not changed significantly the survival rate ${ }^{54}$. Thus, the results of our study help to comprehend the migration and invasion by the neoplastic cells of the oral SCC by dynamic interactions between tumor cells and extracellular matrix. Experimental studies with whole SCC section using more careful analyses are needed to corroborate or not the present findings.

The present histologic study concluded that fibronectin, tenascin and type I collagen were produced and deposited in the stromal space and in the basement membrane of SCC. The more important conclusion from the present in vitro study was that SCC cells produced tenascin molecules much more in the stroma of tongue than in the lip.

\section{Acknowledgements}

This study was supported by the National Council of Scientific and Technological Development from the Ministry of the Science and Technology (MCT/CNPq), Government of Brazil.

\section{Conflict of Interest Statement}

The authors declare no conflict of interest.

\section{REFERENCES}

1. Aparna M, Rao L, Kunhikatta V, Radhakrishnan R. The role of MMP-2 and MMP-9 as prognostic markers in the early stages of tongue squamous cell carcinoma. J Oral Pathol Med. 2015 May;44(5):345-52. doi: 10.1111/jop.12245.

2. Bsoul SA, Huber MA, Terezhalmy GT Squamous cell carcinoma of the oral tissues: a comprehensive review for oral healthcare providers. J Contemp Dent Pract. 2005 Nov 15;6(4):1-16.

3. Kamarajan P, Garcia-Pardo A, D'Silva NJ, Kapila YL. The CS1 segment of fibronectin is involved in human OSCC pathogenesis by mediating OSCC cell spreading, migration, and invasion. BMC Cancer. 2010 Jun 25;10:330. doi: 10.1186/1471-2407-10-330.

4. Metwaly H, Maruyama S, Yamazaki M, Tsuneki M, Abé T, Jen KY, et al. Parenchymal-stromal switching for extracellular matrix production on invasion of oral squamous cell carcinoma. Hum Pathol. 2012 Nov;43(11):1973-81. doi: 10.1016/j.humpath.2012.02.006. 
5. Bodner L, Manor E, Friger MD, van der Waal I. Oral squamous cell carcinoma in patients twenty years of age or younger--review and analysis of 186 reported cases. Oral Oncol. 2014 Feb;50(2):84-9. doi: 10.1016/j.oraloncology.2013.11.001.

6. Qi G, Ogawa I, Kudo Y, Miyauchi M, Siriwardena BS, Shimamoto F, et al. Aurora-B expression and its correlation with cell proliferation and metastasis in oral cancer. Virchows Arch. 2007 Mar;450(3):297-302.

7. Siriwardena BS, Kudo Y, Ogawa I, Udagama MN, Tilakaratne WM, Takata T. VEGF-C is associated with lymphatic status and invasion in oral cancer. J Clin Pathol. 2008 Jan;61(1):103-8.

8. Gallo O, Masini E, Bianchi B, Bruschini L, Paglierani M, Franchi A. Prognostic significance of cyclooxygenase-2 pathway and angiogenesis in head and neck squamous cell carcinoma. Hum Pathol. 2002 Jul;33(7):708-14

9. Vigneswaran N, Zhao W, Dassanayake A, Muller S, Miller DM, Zacharias W. Variable expression of cathepsin B and D correlates with highly invasive and metastatic phenotype of oral cancer. Hum Pathol. 2000 Aug;31(8):931-7.

10. Siriwardena BS, Tilakaratne A, Amaratunga EA, Udagama MN, Ogawa I, Kudo Y, et al. Analysis of histopathological and immunohistochemical differences of oral squamous cell carcinoma in young and old patients in Sri Lanka. J Oral Pathol Med. 2007 Jul;36(6):357-62

11. Thorup AK, Reibel J, Schiodt M, Stenersen TC, Therkildsen MH, Carter WG, et al. Can alterations in integrin and laminin-5 expression be used as markers of malignancy? APMIS. 1998 Dec;106(12):1170-80.

12. Pereira AL, Veras SS, Silveira EJ, Seabra FR, Pinto LP, Souza LB, et al. The role of matrix extracellular proteins and metalloproteinases in head and neck carcinomas: an updated review. Braz $\mathrm{J}$ Otorhinolaryngol. 2005 Jan-Feb;71(1):81-6.

13. Foda HD, Zucker S. Matrix metalloproteinases in cancer invasion, metastasis and angiogenesis. Drug Discov Today. 2001 May 1;6(9):478-482

14. Thomas GJ, Speight PM. Cell adhesion molecules and oral cancer. Crit Rev Oral Biol Med 2001;12(6):479-98.

15. Kosmehl H, Berndt A, Katenkamp D. Molecular variants of fibronectin and laminin: structure, physiological occurrence and histopathological aspects. Virchows Arch. 1996 Dec;429(6):311-22.

16. Chiquet-Ehrismann R, Hagios $C$, Schenk $S$. The complexity in regulating the expression of tenascins. Bioessays. 1995 Oct;17(10):873-8.

17. Ronnov-Jessen L, Petersen OW, Bissell MJ. Cellular changes involved in conversion of normal to malignant breast: importance of the stromal reaction. Physiol Rev. 1996 Jan;76(1):69-125.

18. Tiitta $\mathrm{O}$, Happonen RP, Virtanen I, Luomanen M. Distribution of tenascin in oral premalignant lesions and squamous cell carcinoma. J Oral Pathol Med. 1994 Nov;23(10):446-50

19. Tuxhorn JA, Ayala GE, Rowley DR. Reactive stroma in prostate cancer progression. J Urol. 2001 Dec;166(6):2472-83.

20. Jacobs TW, Schnitt SJ, Tan X, Brown LF. Radial scars of the breast and breast carcinomas have similar alterations in expression of factors involved in vascular stroma formation. Hum Pathol. 2002 Jan;33(1):29-38.

21. van Kempen LC, Rijntjes J, Claes A, Blokx WA, Gerritsen MJ, Ruiter DJ, et al. Type I collagen synthesis parallels the conversion of keratinocytic intraepidermal neoplasia to cutaneous squamous cell carcinoma. J Pathol. 2004 Nov;204(3):333-9.

22. Dantas DD, Ramos CC, Costa AL, Souza LB, Pinto LP. Clinical-pathological parameters in squamous cell carcinoma of the tongue. Braz Dent J. 2003;14(1):22-5. 
23. Cruz MC, Pereira AL, Lopes FF, Nonaka CF, Silva RR, Freitas R de A, et al. Immunohistochemical expression of E-cadherin and CD44v6 in squamous cell carcinomas of the lower lip and tongue. Braz Dent J. 2009;20(1):64-9

24. Qaisi M, Vorrasi J, Lubek J, Ord R. Multiple primary squamous cell carcinomas of the oral cavity. J Oral Maxillofac Surg. 2014 Aug;72(8):1511-6. doi: 10.1016/j.joms.2014.03.012.

25. Bryne M. Is the invasive front of an oral carcinoma the most important area for prognostication? Oral Dis. 1998;4(2):70-7.

26. da Silveira EJ, Miguel MC, Lima KC, Freitas Rde A, de Morais ML, Queiroz LM. Analysis of local immunity in squamous cell carcinoma of the tongue and lower lip. Exp Mol Pathol. 2010 Feb;88(1):171-5. doi: 10.1016/j.yexmp.2009.11.009.

27. Lin CW, Sun MS, Wu HC. Podocalyxin-like 1 is associated with tumor aggressiveness and metastatic gene expression in human oral squamous cell carcinoma. Int J Oncol. 2014 Aug;45(2):710-8. doi: $10.3892 /$ ijo.2014.2427.

28. Al-Rajhi N, Khafaga Y, El-Husseiny J, Saleem M, Mourad W, Al-Otieschan A, et al. Early stage carcinoma of oral tongue: prognostic factors for local control and survival. Oral Oncol. 2000 Nov; 36(6):508-14

29. Kerdpon D, Sriplung H. Factors related to advanced stage oral squamous cell carcinoma in southern Thailand. Oral Oncol. 2001 Apr; 37(3):216-21.

30. Chen YW, Yu EH, Wu TH, Lo WL, Li WY, Kao SY. Histopathological factors affecting nodal metastasis in tongue cancer: analysis of 94 patients in Taiwan. Int J Oral Maxillofac Surg. 2008 Oct;37(10):912-6. doi: 10.1016/j.ijom.2008.07.014.

31. Shrestha P, Sumitomo S, Lee CH, Nagahara K, Kamegai A, Yamanaka T, et al. Tenascin: growth and adhesion modulation--extracellular matrix degrading function: an in vitro study. Eur J Cancer B Oral Oncol. 1996 Mar;32B(2):106-13.

32. Larsen M, Artym VV, Green JA, Yamada KM. The matrix reorganized: extracellular matrix remodeling and integrin signaling. Curr Opin Cell Biol. 2006 Oct;18(5):463-71.

33. Orend G, Chiquet-Ehrismann R. Tenascin-C induced signaling in cancer. Cancer Lett. 2006 Dec;244(2):143-63.

34. Lyons AJ, Bateman AC, Spedding A, Primrose JN, Mandel U. Oncofetal fibronectin and oral squamous cell carcinoma. Br J Oral Maxillofac Surg. 2001 Dec;9(6):471-7.

35. Zidar N, Gale N, Kambic V, Fischinger J. Expression of tenascin and fibronectin in benign epithelial hyperplastic lesions and squamous carcinoma of the larynx. Anticancer Res. 2001 Jan-Feb;21(1A):451-4

36. Yoshida T, Yoshimura E, Numata H, Sakakura Y, Sakakura T. Involvement of tenascin-C in proliferation and migration of laryngeal carcinoma cells. Virchows Arch. 1999 Nov;435(5):496-500

37. Juhasz A, Bardos H, Repassy G, Adany R. Characteristic distribution patterns of tenascin in laryngeal and hypopharyngeal cancers. Laryngoscope. 2000 Jan;110(1):84-92

38. Sekiguchi T, Noguchi M, Nakamori K, Kohama G-I. Clinical significance of interstitial collagen deposition at the invading edge in oral cancer: immunohistochemistry for type I collagen. Int J Clin Oncol. 1997 Mar;2(1):21-8.

39. Kosmehl H, Berndt A, Strassburger S, Borsi L, Rousselle P, Mandel U, et al. Distribution of laminin and fibronectin isoforms in oral mucosa and oral squamous cell carcinoma. Br J Cancer. 1999 Nov;81(6):1071-9.

40. Lyons AJ, Jones J. Cell adhesion molecules, the extracellular matrix and oral squamous carcinoma Int J Oral Maxillofac Surg. 2007 Aug;36(8):671-9. 
41. Ryu MH, Park HM, Chung J, Lee CH, Park HR. Hypoxia-inducible factor-1alpha mediates oral squamous cell carcinoma invasion via upregulation of alpha5 integrin and fibronectin. Biochem Biophys Res Commun. 2010 Feb 26;393(1):11-5. doi: 10.1016/j.bbrc.2010.01.060.

42. Arduino PG, Carrozzo M, Pagano M, Broccoletti R, Scully C, Gandolfo S. Immunohistochemical expression of basement membrane proteins of verrucous carcinoma of the oral mucosa. Clin Oral Investig. 2010 Jun;14(3):297-302. doi: 10.1007/s00784-009-0296-y.

43. Araujo VC, Furuse C, Cury PR, Altemani A, Alves VA, de Araujo NS. Tenascin and fibronectin expression in carcinoma ex pleomorphic adenoma. Appl Immunohistochem Mol Morphol. 2008 Jan;16(1):48-53.

44. Ohtsuka M, Yamamoto H, Oshiro R, Takahashi H, Masuzawa T, Uemura M, et al. Concurrent expression of C4.4A and Tenascin-C in tumor cellsrelates to poor prognosis of esophageal squamous cell carcinoma. Int J Oncol. 2013 Aug;43(2):439-46. doi: 10.3892/ijo.2013.1956.

45. Nagaharu K, Zhang X, Yoshida T, Katoh D, Hanamura N, Kozuka Y, et al. Tenascin C induces epithelial-mesenchymal transition-like change accompanied by SRC activation and focal adhesion kinase phosphorylation in human breast cancer cells. Am J Pathol. 2011 Feb;178(2):754-63. doi: 10.1016/j.ajpath.2010.10.015.

46. Orend $\mathrm{G}$, Chiquet-Ehrismann R. Adhesion modulation by antiadhesive molecules of the extracellular matrix. Exp Cell Res. 2000 Nov;261(1):104-10.

47. Franz M, Hansen T, Borsi L, Geier C, Hyckel P, Schleier P, et al. A quantitative co-localization analysis of large unspliced tenascin- $\mathrm{C}(\mathrm{L})$ and laminin-5/gamma2-chain in basement membranes of oral squamous cell carcinoma by confocal laser scanning microscopy. J Oral Pathol Med. 2007;36(1):6-11.

48. Wang Z, Han B, Zhang Z, Pan J, Xia H. Expression of angiopoietin-like 4 and tenascin C but not cathepsin $\mathrm{C}$ mRNA predicts prognosis of oral tongue squamous cell carcinoma. Biomarkers. 2010 Feb;15(1):39-46. doi: 10.3109/13547500903261362.

49. Wilson DF, Jiang DJ, Pierce AM, Wiebkin OW. Oral cancer: role of the basement membrane in invasion. Aust Dent J. 1999;44(2):93-7.

50. Allon I, Vered M, Buchner A, Dayan D. Stromal differences in salivary gland tumors of a common histopathogenesis but with different biological behavior: a study with picrosirius red and polarizing microscopy. Acta Histochem. 2006;108(4):259-64.

51. Hotary K, Allen E, Punturieri A, Yana I, Weiss SJ. Regulation of cell invasion and morphogenesis in a three-dimensional type I collagen matrix by membrane-type matrix metalloproteinases. 1, 2, and 3. J Cell Biol. 2000 Jun;149(6):1309-23.

52. Menke A, Philippi C, Vogelmann R, Seidel B, Lutz MP, Adler G, et al. Down-regulation of E-cadherin gene expression by collagen type I and type III in pancreatic cancer cell lines. Cancer Res. 2001 Apr;61(8):3508-17.

53. Takayama S, Hatori M, Kurihara Y, Kinugasa Y, Shirota T, Shintani S. Inhibition of TGF-beta1 suppresses motility and invasiveness of oral squamous cell carcinoma cell lines via modulation of integrins and down-regulation of matrix-metalloproteinases. Oncol Rep. 2009 Jan;21(1):205-10.

54. Monteiro LS, Delgado ML, Ricardo S, Garcez F, do Amaral B, Pacheco JJ, et al. EMMPRIN expression in oral squamous cell carcinomas: correlation with tumor proliferation and patient survival. Biomed Res Int. 2014;2014:905680. doi: 10.1155/2014/905680. 